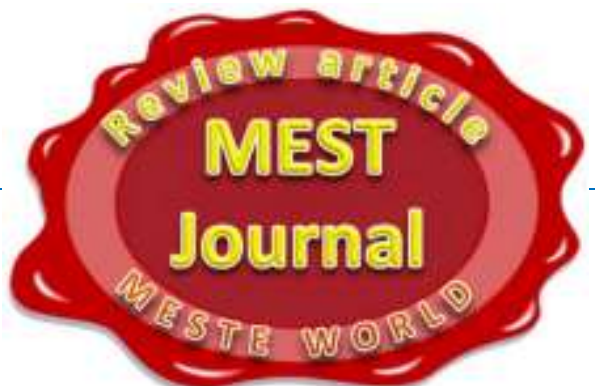

\title{
SUPPORTING GREEN BUSINESS IN EUROPE: ENVIRONMENTAL POLICY INSTRUMENTS
}

\author{
Bohdana Stepanenko-Lypovyk \\ Institute for Economics and Forecasting, Ukrainian National Academy of Sciences, \\ 26, Panasa Myrnoho St., Kyiv, 01001, Ukraine
}

\author{
() MESTE NGO \\ JEL category: H, O, H23, K32, O13, O29
}

\begin{abstract}
Summary:
The article is devoted to the analysis of European countries financial policy in supporting green business development. Special attention is paid to the definition of the role of the state in maintenance of environmental goods and services market growth, that envisaged analysis of the main directions of environmental taxation, environmental expenditures and other environmental policy instruments. The carried out research enabled to determine countries, which invest the most financial resources in the improvement of the environment that assists to create better living conditions for the society. Also shown the economic expediency of green business development that helped to make the conclusion that this activity has sufficiently high profitability and creates a significant contribution to development of national economies.
\end{abstract}

\section{Keywords:}

green business, environmental goods, environmental services, environmental taxes, environmental expenditures, public-private partnership

\section{Introduction - The Green business case for a Green Economy}

The issue of global climate changes and environment protection are becoming more and more actual in the existing conditions of the world economy development. The majority of the developed economies have chosen the strategy of sustainable development as one of the main

The address of the author:

Bohdana Stepanenko-Lypovyk

麦”' BohStep@gmail.com directions in the XXIth century. This strategy is a new model of development, which aspires to improve the economic, environmental and social conditions of the state functioning. Such model is based on the theories of technological dynamics, neo-malthusianism, neo-keynesianism and can be realized through implantation of green economy principles in business activity.

As the industrial activity is today's main source of environment pollution, the key attention of present-day researches is focused on the issue 
of applying in industry the technologies and business-processes, that are able to reduce the negative influence of business activity on the environment. In consequence of spreading of the ideas of The Club of Rome, UNEP and other organizations, a new direction of the economic activity - green business - started to develop in the last years.

Green business, being one of the basic components of green economy, is an activity, which primary objected on getting profit from the sale of ecological goods and services (EGS): a) the production and providing of which envisages the use of the methods and technologies that aim to minimize the integral ecologically destructive impact on the environment; b) the use of which creates maximally ecologically favorable living conditions for the society in both short-term and long-term periods. In addition to the traditional functions of entrepreneurial activity green business has its own specific functions, namely: satisfaction of environmental needs of society, protection of natural environment, minimization of ecologically destructive impact of business activity, providing formation of ecological consciousness, preservation of natural capital.

Thus, the concept of green business suggests that production of environmental goods and servicesis carried out in the sustainable way, and assists improving of the environmental and social living conditions.

\section{The state role in supporting of the green business development}

A conversion from the extensive type of economic development to the sustainable requires the use minimization of non-renewable natural resources and the effective use of renewable ones, improvement of environmental quality, strengthening of the state's environmental security and should lead to stable economy growth. Such transition supposes to generate and introduce the financial mechanism of green business development, which would create favorable conditions for implamantation of the environmental management at enterprises, expanding of the EGS production, conducting green $R \& D$ etc.
Nowdays exclusively position in relation to state interference in the development of green business is not elaborated. Such scientists, as James Meadowcroft (1997) and Michael Redclift (1993) believe that sustainable development requires the centralized planning, which, in its turn, should be supported by the high degree of state interference. At the same time, David Pearce (Pearce D., Markandya A., Barbier E., 1989; Pearce D., Barbier E., 2000) notes, that the centralized planning is inappropriate for sustainable development and that it should be carried out by means of market decentralizing economic tools. On the author's opinion, green business in it's infancy stage requires the state intervention and after achieving the level of self-funding can develop on the market conditions. This is because the traditional entrepreneurs usually ignore the environmental methods of the production aspiring only to maximize their profits and the state can create the conditions which would stimulate enterprises to improve the environment. The establishment of green business considerably depends on the state support and requires, first of all, development of the legal base and economic instruments.

\section{Environmental policy instruments for stimulation of the EGS market development}

After the adoption of sustainable development strategy in majority of European countries in 2001, the social unity and environmental protection received the immediate state support (Commission of the European Communities, 2009). It has been established by the governments of EU member countries, which support development of environmental goods and services market, that they may use the following groups of tools:

- informative (trainings, recommendations, etc.);

- partner (dialogs, partner programs and other ones);

- financial and economic (economic initiatives, privileges, grants, etc.);

- regulative (laws, norms, rules, requirements, etc.);

- hybrid (strategies, activity plans, etc.). 
The government of each country solves independently, which tool to be chosen for stimulation of green business development. Basically it depends on the country's internal economic and financial factors. The most used group of instruments of supporting green business development among the European countries is the regulative one, as its usage envisages creation of the proper legal base both on the state and local levels. The legislative implamantation of green business principles is very important, because that creates the basement for its development. The other frequently used group of tools is financial and economic one, which is mostly formed from environmental payments and expenditures.

\subsection{Tax-based environmental policy instruments to stimulate green business}

Nowadays in European countries there are quite a lot of different environmental taxes, one of the purpose of which is to improve the environmental living conditions. These payments can be grouped according to the general taxbase (see Table 1).

The highest number of environmental taxes is used in Denmark, the lowest taxation, as a tool of supporting environmental protection, is used in Cyprus. From Table 1 it is clear that in Europe among the most widespread objects of environmental taxation are the usage of resources, environmental pollution, wastes collection and utilization.

It could be mentioned that in 2010 the highest volume of environmental payments was formed in Germany ( $€ 54164.0 \mathrm{mln}$ ) and UK ( $€ 40603.37$ $\mathrm{mln}$ ). However, the share of these payments as a percentage of GDP accounts only for 2.3 and $2.6 \%$ respectively. In such countries as Denmark $(4.8 \%)$, Netherlands $(4.0 \%)$ and Slovenia (3.6\%), the amount of the environmental taxes as a percentage of GDP is considerably higher. If to take into consideration that exactly in Germany and UK the establishment of green business began, then such data can testify that environmental taxes is more effective supporing instrument for the countries in which green business is on the infanty stage, and in the countries where this direction of activity is developed it is needed to apply other tools.

Table 1. Environmental taxes in European countries grouped by the general tax-base (European Environment Agency, 2012)

\begin{tabular}{|c|c|c|c|c|c|c|c|c|}
\hline \multirow[b]{2}{*}{ Country } & \multicolumn{8}{|c|}{ General tax-base } \\
\hline & 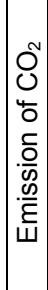 & 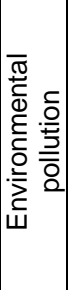 & 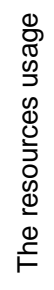 & 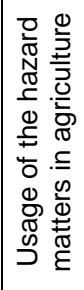 & 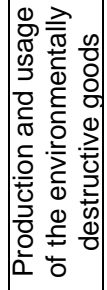 & 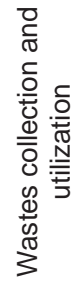 & 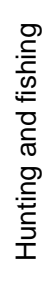 & 离 \\
\hline Austria & $\mathbf{Y}$ & $\mathbf{Y}$ & $\mathbf{Y}$ & $\mathrm{N}$ & $\mathrm{N}$ & $\mathbf{Y}$ & $\mathbf{Y}$ & $\mathbf{Y}$ \\
\hline Belgium & $\mathrm{N}$ & $\mathbf{Y}$ & $\mathbf{Y}$ & $\mathbf{Y}$ & $\mathrm{N}$ & $\mathrm{N}$ & $\mathrm{N}$ & $\mathbf{Y}$ \\
\hline Bulgaria & $\mathrm{N}$ & $\mathbf{Y}$ & $\mathbf{Y}$ & $\mathrm{N}$ & $\mathbf{Y}$ & $\mathrm{N}$ & $\mathbf{Y}$ & $\mathbf{Y}$ \\
\hline Cyprus & $\mathrm{N}$ & $\mathrm{N}$ & $\mathbf{Y}$ & $\mathrm{N}$ & $\mathrm{N}$ & $\mathrm{N}$ & $\mathrm{N}$ & $\mathbf{Y}$ \\
\hline $\begin{array}{l}\text { Czech } \\
\text { Republic }\end{array}$ & $\mathrm{N}$ & $\mathbf{Y}$ & $\mathbf{Y}$ & $\mathrm{N}$ & $\mathbf{Y}$ & $\mathbf{Y}$ & $\mathrm{N}$ & $\mathbf{Y}$ \\
\hline Denmark & $\mathbf{Y}$ & $\mathbf{Y}$ & $\mathbf{Y}$ & $\mathbf{Y}$ & $\mathbf{Y}$ & $\mathbf{Y}$ & $\mathbf{Y}$ & $\mathbf{Y}$ \\
\hline Estonia & $\mathrm{N}$ & $\mathbf{Y}$ & $\mathbf{Y}$ & $\mathrm{N}$ & $\mathrm{N}$ & $\mathbf{Y}$ & $\mathbf{Y}$ & $\mathbf{Y}$ \\
\hline Finland & $\mathbf{Y}$ & $\mathbf{Y}$ & $\mathbf{Y}$ & $\mathbf{Y}$ & $\mathbf{Y}$ & $\mathbf{Y}$ & $\mathbf{Y}$ & $\mathbf{Y}$ \\
\hline France & $\mathbf{Y}$ & $\mathbf{Y}$ & $\mathbf{Y}$ & $\mathrm{N}$ & $\mathrm{N}$ & $\mathbf{Y}$ & $\mathrm{N}$ & $\mathbf{Y}$ \\
\hline Germany & $\mathrm{N}$ & $\mathrm{N}$ & $\mathbf{Y}$ & $\mathrm{N}$ & $\mathbf{Y}$ & $\mathrm{N}$ & $\mathrm{N}$ & $\mathbf{Y}$ \\
\hline Hungary & $\mathrm{N}$ & $\mathbf{Y}$ & $\mathbf{Y}$ & $\mathrm{N}$ & $\mathbf{Y}$ & $\mathbf{Y}$ & $\mathrm{N}$ & $\mathbf{Y}$ \\
\hline Ireland & $\mathrm{N}$ & $\mathrm{N}$ & $\mathbf{Y}$ & $\mathrm{N}$ & $\mathbf{Y}$ & $\mathrm{N}$ & $\mathrm{N}$ & $\mathbf{Y}$ \\
\hline Italy & $\mathrm{N}$ & $\mathbf{Y}$ & $\mathbf{Y}$ & $\mathbf{Y}$ & $\mathbf{Y}$ & $\mathbf{Y}$ & $\mathrm{N}$ & $\mathbf{Y}$ \\
\hline Latvia & $\mathrm{N}$ & $\mathbf{Y}$ & $\mathbf{Y}$ & $\mathrm{N}$ & $\mathbf{Y}$ & $\mathbf{Y}$ & $\mathrm{N}$ & $\mathbf{Y}$ \\
\hline Lithuania & $\mathrm{N}$ & $\mathbf{Y}$ & $\mathrm{N}$ & $\mathrm{N}$ & $\mathbf{Y}$ & $\mathbf{Y}$ & $\mathbf{Y}$ & $\mathbf{Y}$ \\
\hline Luxemburg & $\mathrm{N}$ & $\mathrm{N}$ & $\mathbf{Y}$ & $\mathrm{N}$ & $\mathrm{N}$ & $\mathrm{N}$ & $\mathrm{N}$ & $\mathbf{Y}$ \\
\hline Malta & $\mathbf{Y}$ & $\mathrm{N}$ & $\mathbf{Y}$ & $\mathrm{N}$ & $\mathrm{N}$ & $\mathbf{Y}$ & $\mathbf{Y}$ & $\mathbf{Y}$ \\
\hline Netherlands & $\mathrm{N}$ & $\mathbf{Y}$ & $\mathbf{Y}$ & $\mathrm{N}$ & $\mathbf{Y}$ & $\mathbf{Y}$ & $\mathbf{Y}$ & $\mathbf{Y}$ \\
\hline Poland & $\mathrm{N}$ & $\mathbf{Y}$ & $\mathbf{Y}$ & $\mathrm{N}$ & $\mathbf{Y}$ & $\mathbf{Y}$ & $\mathbf{Y}$ & $\mathbf{Y}$ \\
\hline Portugal & $\mathrm{N}$ & $\mathrm{N}$ & $\mathbf{Y}$ & $\mathrm{N}$ & $\mathbf{Y}$ & $\mathrm{N}$ & $\mathbf{Y}$ & $\mathbf{Y}$ \\
\hline Romania & $\mathbf{Y}$ & $\mathbf{Y}$ & $\mathrm{N}$ & $\mathrm{N}$ & $\mathrm{N}$ & $\mathbf{Y}$ & $\mathbf{Y}$ & $Y$ \\
\hline Slovakia & $\mathrm{N}$ & $\mathbf{Y}$ & $\mathbf{Y}$ & $\mathrm{N}$ & $\mathrm{N}$ & $\mathbf{Y}$ & $\mathrm{N}$ & $\mathbf{Y}$ \\
\hline Slovenia & $\mathbf{Y}$ & $\mathrm{N}$ & $\mathbf{Y}$ & $\mathbf{Y}$ & $\mathbf{Y}$ & $\mathbf{Y}$ & $\mathrm{N}$ & $\mathbf{Y}$ \\
\hline Spain & $\mathrm{N}$ & $\mathbf{Y}$ & $\mathbf{Y}$ & $\mathrm{N}$ & $\mathbf{Y}$ & $\mathbf{Y}$ & $\mathrm{N}$ & $\mathrm{N}$ \\
\hline Sweden & $\mathbf{Y}$ & $\mathrm{N}$ & $\mathbf{Y}$ & $\mathbf{Y}$ & $\mathbf{Y}$ & $\mathbf{Y}$ & $\mathbf{Y}$ & $\mathbf{Y}$ \\
\hline UK & $\mathbf{Y}$ & $\mathbf{Y}$ & $\mathbf{Y}$ & $\mathrm{N}$ & $\mathrm{N}$ & $\mathrm{N}$ & $\mathrm{N}$ & $\mathrm{N}$ \\
\hline
\end{tabular}

Note: "Y $Y$ » direction is the object of taxation; «N»-direction is not the object of taxation.

\subsection{Environmental expenditures instrument to support green business}

Another environmental policy instrument which advanced sustainable development is budget financing. In Europe there are quite a lot of programs of the state financial support of environmental protection and green business development, that are generalized in Table 2.

The basic object of the budget financing, as the environmental policy instrument, in Europe is investing in green business. Also in European countries at the state levels are actively financed programs connected with the improvement of energy efficiency. There are 20 countries 
marked in Table 2 that have special state support programs for this direction. Less actively EU countries financially support agriculture and nature protection (only in one country from 20 this direction of financing is presented). All mentioned testifies, that governments of the European countries actively assist the sustainable development due to stimulation of the innovative activity in the sphere of green technologies and green business.

Table 2. Main directions of the environmental expenditures in European countries (European Environment Agency, 2012)

\begin{tabular}{|c|c|c|c|c|c|c|c|c|c|c|c|c|}
\hline \multirow[b]{2}{*}{ Country } & \multicolumn{12}{|c|}{ Direction of environmental expenditures } \\
\hline & 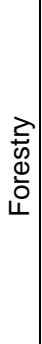 & $\begin{array}{l}\frac{0}{3} \\
\frac{1}{5} \\
. \frac{0}{5} \\
\frac{0}{4}\end{array}$ & 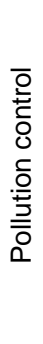 & $\begin{array}{l}\frac{0}{0} \\
\frac{0}{0} \\
\text { d } \\
\text { 은 }\end{array}$ & $\Phi$ & 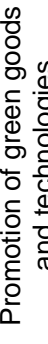 & 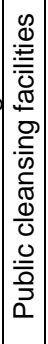 & 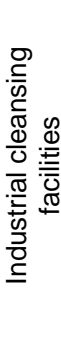 & 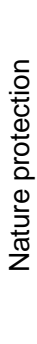 & 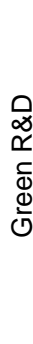 & 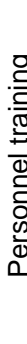 & 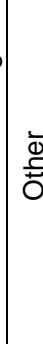 \\
\hline Austria & $\mathbf{Y}$ & $\mathrm{N}$ & $\mathrm{N}$ & $\mathrm{N}$ & $\mathrm{N}$ & $\mathrm{N}$ & $\mathrm{N}$ & $\mathrm{N}$ & $\mathrm{N}$ & $\mathrm{N}$ & $\mathrm{N}$ & $\mathrm{N}$ \\
\hline Belgium & $\mathrm{N}$ & $\mathbf{Y}$ & $\mathbf{Y}$ & $\mathbf{Y}$ & $\mathbf{Y}$ & $\mathbf{Y}$ & $\mathbf{Y}$ & $\mathbf{Y}$ & $\mathbf{Y}$ & $\mathbf{Y}$ & $\mathbf{Y}$ & $\mathbf{Y}$ \\
\hline Bulgaria & $\mathrm{N}$ & $\mathrm{N}$ & $\mathbf{Y}$ & $\mathbf{Y}$ & $\mathbf{Y}$ & $\mathrm{N}$ & $\mathbf{Y}$ & $\mathbf{Y}$ & $\mathrm{N}$ & $\mathbf{Y}$ & $\mathbf{Y}$ & $\mathbf{Y}$ \\
\hline Cyprus & $\mathrm{N}$ & $N$ & $Y$ & $\mathbf{Y}$ & $\mathrm{N}$ & $\mathbf{Y}$ & $\mathbf{Y}$ & $\mathbf{Y}$ & $\mathrm{N}$ & $\mathrm{N}$ & $\mathrm{N}$ & $\mathrm{N}$ \\
\hline $\begin{array}{l}\text { Czech } \\
\text { Republi }\end{array}$ & $\mathbf{Y}$ & $\mathrm{N}$ & $\mathbf{Y}$ & $\mathbf{Y}$ & $\mathbf{Y}$ & $\mathrm{N}$ & $\mathbf{Y}$ & $\mathrm{N}$ & $\mathrm{N}$ & $\mathbf{Y}$ & $\mathbf{Y}$ & Y \\
\hline Denmark & $\mathrm{N}$ & $\mathrm{N}$ & $\mathbf{Y}$ & $\mathbf{Y}$ & $\mathbf{Y}$ & $Y$ & $N$ & $\mathbf{Y}$ & $\mathrm{N}$ & $\mathbf{Y}$ & $\mathrm{N}$ & $Y$ \\
\hline Estonia & $\mathrm{N}$ & $\mathrm{N}$ & $\mathrm{N}$ & $\mathrm{N}$ & $\mathbf{Y}$ & $\mathbf{Y}$ & $\mathbf{Y}$ & $\mathbf{Y}$ & $\mathrm{N}$ & $\mathbf{Y}$ & $\mathbf{Y}$ & $\mathbf{Y}$ \\
\hline Finland & $\mathrm{N}$ & $\mathrm{N}$ & $\mathrm{N}$ & $\mathbf{Y}$ & $\mathbf{Y}$ & $\mathbf{Y}$ & $\mathbf{Y}$ & $\mathbf{Y}$ & $\mathrm{N}$ & $\mathbf{Y}$ & $\mathrm{N}$ & $\mathbf{Y}$ \\
\hline France & $\mathrm{N}$ & $\mathrm{N}$ & $\mathrm{N}$ & $\mathbf{Y}$ & Y & $\mathrm{N}$ & $N$ & $\mathbf{Y}$ & $\mathrm{N}$ & $\mathbf{Y}$ & $\mathrm{N}$ & $\mathrm{N}$ \\
\hline Greece & $\mathrm{N}$ & $\mathrm{N}$ & $\mathrm{N}$ & $\mathbf{Y}$ & $\mathbf{Y}$ & $\mathbf{Y}$ & $N$ & $\mathbf{Y}$ & $\mathrm{N}$ & $\mathbf{Y}$ & $\mathrm{N}$ & $\mathbf{Y}$ \\
\hline Hungary & $\mathrm{N}$ & $\mathrm{N}$ & $\mathrm{N}$ & $\mathbf{Y}$ & $Y$ & $r$ & $\mathrm{~N}$ & $\mathrm{~N}$ & $\mathrm{~N}$ & $\mathrm{~N}$ & $\mathrm{~N}$ & $\mathrm{~N}$ \\
\hline Italy & $\mathrm{N}$ & $\mathrm{N}$ & $\mathrm{N}$ & $\mathbf{Y}$ & $\mathbf{Y}$ & . & $\mathrm{N}$ & $\mathrm{N}$ & $\mathrm{N}$ & $\mathbf{Y}$ & $\mathrm{N}$ & $\mathbf{Y}$ \\
\hline Lithuania & $\mathrm{N}$ & $\mathrm{N}$ & $\mathrm{N}$ & $\mathbf{Y}$ & $\mathbf{Y}$ & $\mathbf{Y}$ & $\mathbf{Y}$ & $\mathbf{Y}$ & $\mathrm{N}$ & $\mathbf{Y}$ & $\mathrm{N}$ & $\mathbf{Y}$ \\
\hline Netherlands & $\mathrm{N}$ & $\mathrm{N}$ & $\mathbf{Y}$ & $\mathbf{Y}$ & $\mathbf{Y}$ & v & $\mathrm{N}$ & $\mathbf{Y}$ & $\mathrm{N}$ & $\mathbf{Y}$ & $\mathbf{Y}$ & $\mathbf{Y}$ \\
\hline Poland & $\mathrm{N}$ & $\mathrm{N}$ & $\mathrm{N}$ & $\mathrm{N}$ & $\mathrm{N}$ & $\mathrm{N}$ & $\mathrm{N}$ & $\mathrm{N}$ & $\mathrm{N}$ & $\mathrm{N}$ & $\mathrm{N}$ & $\mathrm{N}$ \\
\hline Slovakia & $\mathrm{N}$ & $\mathrm{N}$ & $\mathbf{Y}$ & $\mathbf{Y}$ & $\mathbf{Y}$ & Y & $\mathbf{Y}$ & $\mathbf{Y}$ & $\mathrm{N}$ & $\mathbf{Y}$ & $Y$ & $\mathrm{~N}$ \\
\hline Slovenia & $\mathrm{N}$ & $\mathrm{N}$ & $\mathbf{Y}$ & $Y$ & $Y$ & $\mathbf{Y}$ & $\mathbf{Y}$ & $\mathbf{Y}$ & $\mathrm{N}$ & $\mathrm{N}$ & $\mathrm{N}$ & $N$ \\
\hline Spain & $\mathrm{N}$ & $\mathrm{N}$ & $\mathrm{N}$ & $\mathbf{Y}$ & $\mathbf{Y}$ & $\mathrm{N}$ & $\mathrm{N}$ & $\mathrm{N}$ & $\mathrm{N}$ & $\mathrm{N}$ & $\mathrm{N}$ & $\mathrm{N}$ \\
\hline Sweden & $\mathbf{Y}$ & $\mathrm{N}$ & $\mathrm{N}$ & $\mathbf{Y}$ & Y & Y & $\mathrm{N}$ & $\mathrm{N}$ & $\mathrm{N}$ & $\mathbf{Y}$ & $\mathrm{N}$ & $\mathbf{Y}$ \\
\hline UK & $\mathrm{N}$ & $\mathrm{N}$ & $\mathrm{N}$ & $\mathrm{N}$ & $\mathbf{Y}$ & $\mathbf{Y}$ & $N$ & $\mathbf{Y}$ & $\mathrm{N}$ & $N$ & Ty & $\mathbf{Y}$ \\
\hline
\end{tabular}

Note: «Y»- direction is financed, «N»-direction is not financed.

According to the volumes of budget financing of environmental programs, such countries as Italy $(€ 12378.0 \mathrm{mln})$, France $(€ 10863.8 \mathrm{mln})$ and Germany $(€ 7690.0 \mathrm{mln})$ lead in Europe. However in Italy and Slovenia, the share of the budget financing of environmental programmes approached to $1 \%$ of GDP, and in Denmark this ratio is $1.1 \%$. Arithmetical mean of the budgetary financing share in GDP among EU countries is $0.4 \%$. Volumes of financial resources, which the state assigns for the green business development from budget, are higher as compared with those invested in environmental protection by subjects of economic activity, as shown in Fig. 1.

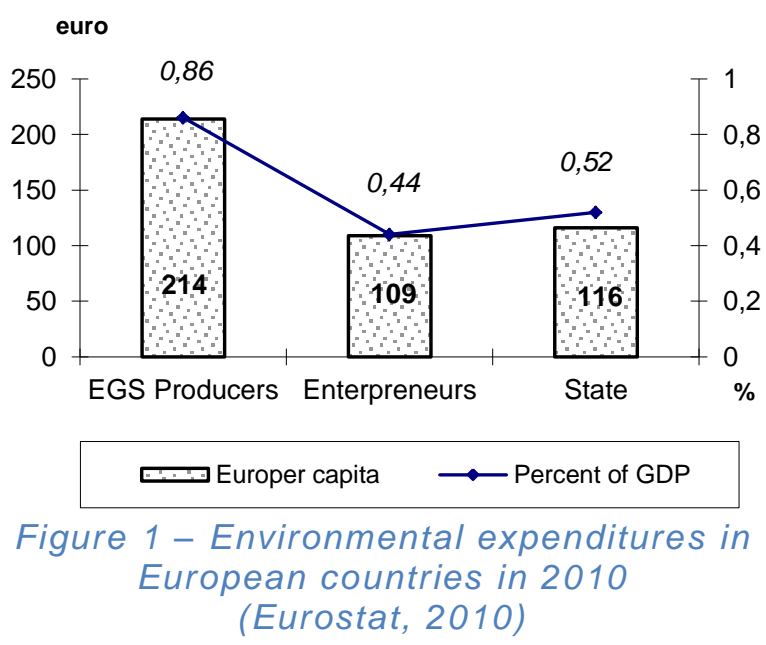

On Figure 1 it can be seen that in 2010 most financial resources assigned for environmental protection were invested by producers of environmental goods and services (approximately €214 per capita). Representatives of other directions of economic activity financed this direction less (on the average $€ 109$ per capita). It testifies that producers of the EGS have environmental consciousness, which induces not only the profit maximization but also aims to provide favorable living conditions for the society.

The volume of environmental expenditures of the EGS producers as a percantage of GDP in some European countries reaches $1.74 \%$ (see Fig.2). Among the European EGS producers most environmental expenditures are maid in such countries as Italy (€257.82 $\mathrm{mln})$ and Denmark $(€ 238.31 \mathrm{mln})$, that accounts for $0.99 \%$ and $0.57 \%$ of GDP respectively. Comparing volumes of environmental expenditures as a percentage of GDP, it is possible to draw the conclusion, that most investments in the environmental protection by the representatives of green busines are maid in Romania. 


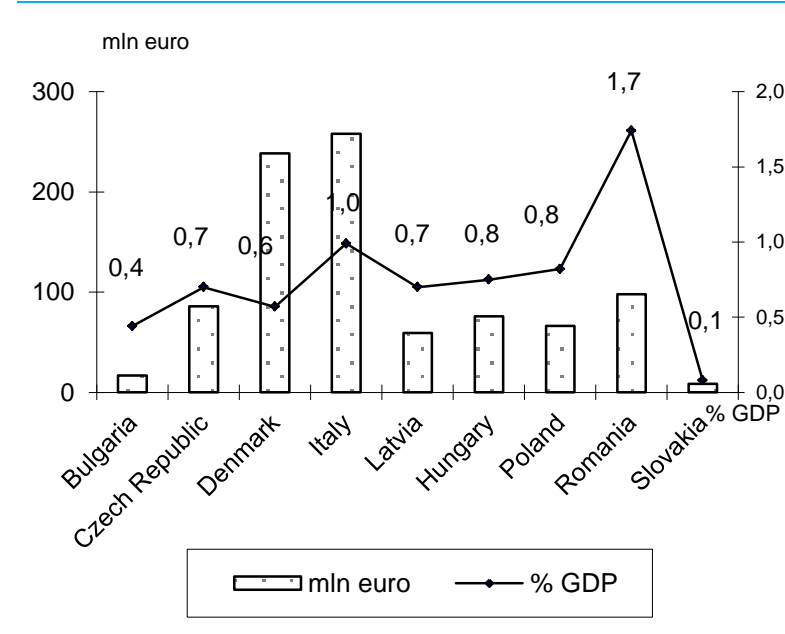

Figure 2 - Environmental expenditures of the EGS producers in European countries in 2010 (Eurostat, 2010)

Usually, on the emerging markets budget financing as the business supporting instrument is not widely used, as it is considered as ineffective method for stimulation of the economic activity development, because, as a rule, enterprises which get the state financial support are not eager to pass to the level of selffunding and are dependable from budget financial resources (Peszko \& Zylicz, 1998). Therefore, governments of the European countries try to limitedly apply this instrument under condition that it is the most effective mean for stimulation of the development of certain activity and will have a short-term character.

\subsection{Other important instruments of green business support}

Deposit-refund systems may be used as a weighty leverage of stimulation of processing and utilization of the environmentally harmful goods. It envisages that the price of potentially polluting products increases on the volume of the legislatively approved rate (rate of refund), which is compensated after the returning (either to the seller or producer) of the used goods, in full volume or partially according to the legislatively fixed rate of compensation. 16 countries of EU use the deposit-refund system as an instrument of environment improvement, majority of them are related to such products and materials, as glass and glassware, packing materials, cars, accumulators, etc. On average, these systems allow to compensate up to $80 \%$ of the product's price, which is an influential stimulus for returning of the used goods and creation of the waste utilization and recycling enterprises.

Another effective instrument, which assists to the EGS production is customers' adherence to environmental consciousness. The environmental orientation of buyers supports growth of solvent demand on the green business products and services, which in its turn leads to purchasing more expensive, but environmentally clean and resource effective goods and services (World business consil for sustainable development, 2011; McConnell, 1997).

Conducted by National Geographic Society, GlobScan, Synovate and Aegis researches show that in Europe a new type of environmentally conscious consumers has already been formed. They are eager to improve the environmental living conditions and ready to pay a higher price for the goods of enhanced environmental quality. These studies also show that $96 \%$ of EU population consider environmental protection as the important factor of their existence.

Another important method of attracting financial resources into projects, where the state and municipal authorities try to preserve control and organize cooperation with investors, is a publicprivate partnership. According to the data of the European Center of Public-Private Partnership Development there were signed 115 agreements in the sphere of public-private partnership in 2010 , with help of which over $€ 18 \mathrm{mln}$ were attracted into various projects. Such countries as UK, Portugal, France, Germany, Spain and Italy are leaders in the number of such agreements. The above mentioned countries accumulate $92 \%$ financial resources available in Europe on the conditions of private-public partnership (Kappeler \& Nemoz, 2010).

The agreements of public-private partnership aim to attract financial resources in the sectors of economy, in which such co-operation is necessary and can have positive consequences both for the state and society. The sphere of environmental protection obtains the least financial resources through public-private partnership, however the only presence of cooperation between the state and society in this direction assists to the green business 
development as it helps to intensify the environmental consciousness of the society.

\section{The economic expediency of the green business}

In EU state support and above mentioned environmental policy instruments have helped green business to develop in the different directions of economic activity. By turnover, employment and created added value the EGS producers lead in such directions as manufacturing, production of drinking water, cleaning of sewage, R\&D in the field of green technologies. In 2009 the highest profit rate had such EGS market directions, as trade (29\%) and green $R \& D(24 \%)$, while in other industries the profit rate of green business is below $20 \%$, and for manufacturing this index is the lowest and accounts for $16 \%$ (Eurostat, 2010). Besides the profit rate is varied depending on a country. France (€14 $341 \mathrm{mln})$ and Italy (€13 $480 \mathrm{mln}$ ) have the highest profits from the sale of EGS. It should be mentioned, that exactly in these countries the financial state support of green business is the highest, and such level of profitability can be the consequence of the active state support of this activity. The lowest share from the EGS sales is in Slovakia and accounts only for $€ 30.8 \mathrm{mln}$.

From above mentioned, it's possible to draw the conclusion, that environmental consciousness of society is increasing year by year, that assists to the demand growth on EGS in Europe. As the production of these goods has a sufficiently high profit rate (on the average $20 \%$ ), the green business makes considerable contribution onto development of national economies of the European countries.

\section{CONCLUSIONS}

Thus, implementation of the environmental policy instruments, their period of usage and role in achievment of sustainable development in EU depend much on availability of acomulation of financial resources, which are needed and may be invested in development of such tools. For this reason in the European countries regional funds for supporting of environmental protection are created, the proper resources from the budgets of EU member countries are assigned for development of the instruments of financial mechanism of green business establishment. As the overall objective of sustainable development will be attained only when green business will become the self-funding type of activity. Thus, in Europe at the state level the powerful system of stimulation of green business development is created, which envisages co-operation of the followings elements: legal regulation of the environmental protection and green business activity; economic instruments; economic levers; institutional support of environmental management and environmental protection. The enhance of environmental consciousness of European nations also assists to the growth of demand for environmental goods and services in the member countries of EU, the production of which has sufficiently high profitability and creates a considerable contribution to development of national economies.

\section{Works Cited}

Commission of the European Communities. (2009). Mainstreaming sustainable development into EU policies: 2009 Review of the European Union Strategy for Sustainable Development. Retrieved from http://eur-lex.europa.eu

European Environment Agency. (2012). OECD/EEA database on environmentally related taxes, fees and charges, other economic instruments and voluntary approaches used in environmental policy and natural resources management. Retrieved from http://www2.oecd.org/ecoinst/queries/.

Eurostat. (2010). Environmental statistics and accounts in Europe. Retrieved from http://epp.eurostat.ec.europa.eu/cache/ITY_OFFPUB/KS-32-10-283/EN/KS-32-10-283EN.PDF/. 
Kappeler A., \& Nemoz M. (2010). EIB Economic and Financial Report: Public - Private Partnerships in Europe - Before and During the Recent Financial Crisis. Luxemburg: ElB. Retrieved from http://www.eib.org/attachments/efs/efr_2010_v04_en.pdf

McConnell, K. (1997). Income and demand for environmental quality. Environment and development Economics, Vol 2, 383-400.

Meadowcroft, J. (1997). Planning for sustainable development: insights from the literatures of political science. European Journal of Political Research, Vol. 31, 427-454.

Pearce, D., \& Barbier, E. (2000). Blueprint for a Sustainable Economy. London: Earthscan.

Pearce, D., Markandya A., \& Barbier E. (1989). Blueprint for a green economy. London: Routledge.

Peszko, G., \& Zylicz, T. (1998). Envoronmental financing in European economies in transition. Environmental and resource economics, Vol. 11(3-4), 521-538.

Redclift, M. (1993). Sustainable Development: Needs, Values, Rights. Environmental Values, Vol. 2, 3-20.

World business counsil for sustainable development. (2011). Sustainable consumption Facts and Trends. Retrieved from http://www.docstoc.com/docs/83452925/The-Business-Role-FocusArea/.

Received for publication: $\quad 25.09 .2012$

Revision received: $\quad 05.12 .2012$

Accepted for publication: $\quad$ 21.12.2012

\section{How to cite this article?}

Style - APA Sixth Edition:

Stepanenko-Lypovyk, B. (2013, 01 15). Supporting green business in Europe: environmental policy instruments. (Z. Čekerevac, Ed.) MEST Journal, 1(1), 58-64. Retrieved from

www.meste.org/mest/MEST 1 2013/ 06.pdf. doi: 10.12709/mest.01.01.01.06.pdf

Style - Chicago Fifteenth Edition:

Stepanenko-Lypovyk, Bohdana. "Supporting green business in Europe: environmental policy

instruments." Edited by Zoran Čekerevac. MEST Journal (MESTE NGO) 1, no. 1 (01 2013): 58-64.

Style - GOST Name Sort:

Stepanenko-Lypovyk Bohdana Supporting green business in Europe: environmental policy instruments [Journal] = Supporting green business in Europe // MEST Journal / ed. Čekerevac Zoran. - Belgrade - Toronto : MESTE NGO, 01 15, 2013. - 1 : Vol. 1. - pp. 58-64.

Style - Harvard Anglia:

Stepanenko-Lypovyk, B., 2013. Supporting green business in Europe: environmental policy instruments. MEST Journal, 15 01, 1(1), pp. 58-64.

Style - ISO 690 Numerical Reference:

Supporting green business in Europe: environmental policy instruments. Stepanenko-Lypovyk, Bohdana. [ed.] Zoran Čekerevac. 1, Belgrade - Toronto : MESTE NGO, 01 15, 2013, MEST Journal, Vol. 1, pp. 58-64. 